\title{
Implementation of Internalization Model on Religious Nationalism Value among High School Students: Case Study in SMA PKP JIS
}

\author{
Yayat Wahyat Herianto ${ }^{1}$, Henni Gusfa ${ }^{2}$ \\ \{yayatherianto.yh@gmail.com ${ }^{1}$,henni.gusfa@gmail.com²\} \\ Universitas Mercu Buana, Indonesia ${ }^{1,2}$
}

\begin{abstract}
This study aims to determine the model of internalizing the value of religious nationalism among millennial generations. The considerable number of millennials in Indonesia has a strategic role in developing and actualizing the values of religious nationalism. This study uses a qualitative method with a case study approach in PKP JIS Senior High School. The academic reason for this research was carried out in educational institutions because schools are social units that have a role in social change. The results of this study indicate that the process of internalizing the value of religious nationalism in PKP JIS high school students takes place through various activities, learning processes and participation in the activities held.
\end{abstract}

Keywords: Religious Nationalism, Internalization Model, Millennial Generation, Qualitative.

\section{Introduction}

Everyone needs a communication process to build and synchronize their understanding and comprehension. Scheidel [1] explains the importance of every person to communicate in order to express their identity, build social contact with people around them, and influence others to feel, think or behave the way we want them to. Communication also has functions in changing the opinion of a person or group as well as being a media in the educational process.

In the world of education or school environment, communication process takes place since the students come to school until the end of the learning process. The process that occurs can take several forms. First, during the process of learning and teaching activities, the process of delivering messages from the communicator (teacher) to students (communicant) takes place. Second, there is an interaction between the teacher and students in which there come the existence of management between the teacher and students. Mulyana [2] explains the concept of communication as interaction. Inside the process of communication, there is a process of cause and effect and the process of action and reaction. Third, as stated by Adler and Rodman [3], communication is also understood as the process of responding to the symbolic behavior of others.

Iriantara [4] sees the process of communication in the world of education emphasizes more on efforts to maintain and defend values to encourage change. While, Fiske [5] sees communication from two points of view: first, as the process of delivering or transmitting messages and second, as the making and exchanging of meanings which are often referred to 
as "semiotics". These two opinions reinforce what practically happens in the education or school units.

Indonesia is a very diverse country with so many cultures, ethnicities, social, religious, artistic, linguistic and other points. This fact is certainly an asset for rreaching an advance development for the nation amid its diversity. But this historical fact would invest bad implications when it is not being well taken care because Indonesian nationality is a historical process that must not be forgotten [6]. Being a nation, its people cannot callously erase the historical role of its heroes. Nowadays, the stages of change towards a developed nation cannot be separated from episodes of pre-nationalist movements, the growth of nationalism and national awareness [7].

In a cultural perspective, Appadurai [8] assesses that Indonesia has just recently formed an "institution" of nation and state. The behavior of its community has not been something yet to be desired if it is viewed from the purposes of 1945 Constitution and Pancasila. The mindset of a nation society is not yet independent and is still overshadowed by the egoethnicity and the mentality of slaves. Some cases of SARA (ethnicity, religion, race, and intergroup relations) background still occur today due to the mindset that has not been resolved by all elements of the nation.

The emergence of various concepts, including religious nationalism is influenced by Gidden's view that humans tend to have ideas. In the concept of nationalism, Kartodirdjo [9] explains that the meaning, realization and purpose of nationalism are always relevant and can be adjusted to the demands of time. This opinion serves millennials space to embody the concept of nationalism which is understood in today's life. However, Kartodirdjo [9] provides the prerequisites of good nationalism: should be able to guarantee the nation unity, individual or group liberty, equality for each individual, the realization of personality and achievement of the nation's future (performance).

Schools are social units that have a role in the process of social change. Through the education process, schools transfer knowledge that can be interpreted as a process of instilling value to individuals [10]. Education can change the mindset of individuals and mobilize it to carry out changes that occur in the educational setting. It is a process of social construction developed by Peter L Berger. The theory of social construction developed by Berger has a focus on meaning and mutual interpretation that have implications for the construction of organizational life (rules, norms, values, actions received by organizations) [11].

In understanding social reality, Della [11] realizes that individuals are able to interpret and act according to the conceptual categories that exist in their minds. For Della, reality does not present itself in its basic or original form but is filtered through the individual's way of seeing things. This explanation is in line with Hidayat's [12] view in which reality is created by individuals. However, the truth coming out of it is relative which is compatible with the specific context that is considered relevant by social community.

Bringing values in every individual together is a concept of internalizing Religious Nationalism. That value is instilled in every millennial student through three processes, namely; transfer of knowledge, transfer of skills or expertise and transfer of attitude or character. Through the process of transferring knowledge, students obtain learning material related to the importance of religious nationalism. Through skills, students need to actualize the knowledge in the practice of school activities, and through attitude improvement process, students are expected to be full of spirit to uphold multiculturalism. The attitude of accepting religious multiculturalism must be manifested in interactions, communication processes, and target visualization. 
According to Berger [13] communication is considered as a process of expression, interaction, and influence that in this process human behavior or other organisms express psychological mechanisms, conditions, beliefs (traits) and through interactions with other individuals, it produces individual's cognitive, emotive impacts and behavior. The values of religious nationalism constitute social realities existed in the realm of Indonesian discourse and are widely used as political jargon. From this value, there is an understanding concept of Berger's main idea in which he describes that reality is built socially and knowledge is the main key term to comprehend it [14].

\section{Model Theory}

Liliwei [15] explains that the model is an imitation of reality. As an imitation, the model is certainly uncompleted, because the model only takes a part of reality. Liliwei further stated that the model provides a specific behavioral perspective. Mahmud [16] details three types of models, namely: (1) as an example to imitate, (2) to strength or to weak existing behaviors and, (3) to facilitate new behaviors.

Meanwhile Mulyana [2] gives an understanding of the model as a representation of a phenomenon, both real and abstract, by showing the most important elements of the phenomenon. With a model according to Mulyana [17] will reduce other communication phenomena that are impossible to explain. Another opinion expressed by Sereno and Martensen [2] explains that the communication model is an ideal description of what is needed in communication.

In communication, Barker [2] mentions three function models, namely (1) describing the communication process, (2) showing visual relations, and (3) finding and improving communication bottlenecks. Meanwhile Buch and Starter revealed five function models namely.

1. Models provide action-oriented information.

2. The model presents information oriented toward the future.

3. The model shows alternative directions for action to be evaluated before being implemented.

4. The model presents giving formal and structured complex problem situations.

The model reflects a scientific approach to not rely on institutions and speculation.

\section{Scrams Communication Model}

The communication model that is suitable with this research is the Schramm model. According to Schramm [2] communication always requires at least three elements namely source (message) and message (destination). Form the three Scramm models in communication, the third model according to the researchers is the smallest reduction level. In the third model regards communication as an interaction with both parties who are present, interpret, encode, transmit and receive signals. There appears to be a continuous feedback circle for sharing information. 


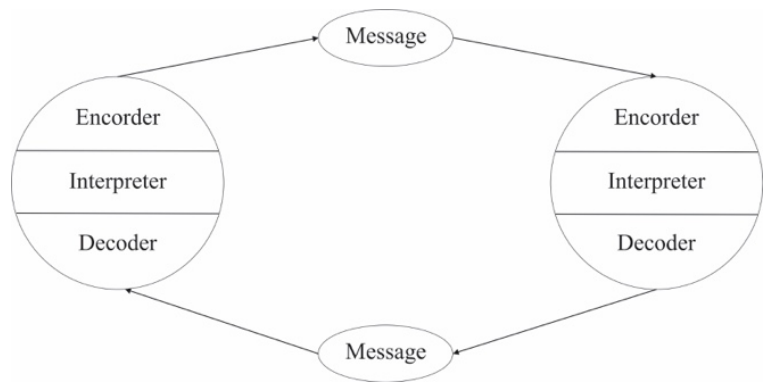

Fig. 1. Schramm Model [2]

This model according to Schram, every person in the communication process as well as an encoder and decoder. We consistently encode signs from our environment, interpret those signs, and become something as a result. This model according to Mulyana [2] is a feedback process that plays an important role in communication, because it tells us how our message is interpreted, both in the form of words as answers, nodding, frowning, yawning and so on.

\section{Research Method}

This research used qualitative approach. Moleong [18] provides a view of qualitative approach as a research which purpose is to understand phenomena being experienced by the subjects holistically using the form of words and languages to describe it in a special natural context, by utilizing scientific methods. Kholifah and Suyadnya [19] show the importance of qualitative research with three main keys, namely; drawing facts from the subject's understanding (Verstehen), conducting detailed and in-depth observations, and maintaining existing efforts. Bourdieu [20] gives an understanding of qualitative research and various realization existed in our sector by referring to theoretical perspectives.

Specifically, there are several characteristics of the qualitative model [21]. First, it constructs social reality and cultural meaning. Second, it focuses on the process of interaction and events. Third, authenticity is the key. Fourth, value is present and tangible which means it is not value-free. Fifth, it is bound to the situation or the context. Sixth, it consists of several cases or subjects. Seventh, it can be classified as thematic analysis. Eighth, researchers are involved.

The type of research used was case studies. According to Yin [22], case study is contemporary because it is bound to the present, whether it is happening or has been completed, but it still has an impact that can be felt when conducting research. In quoting Stake's opinion, Mulyadi [21] gives a detailed explanation of case study as a type of research that focuses on what can be learned specifically. The emphasis on case studies is to maximize the understanding of the cases being studied, not to get generalizations. 


\section{Results and Discussion}

\subsection{School profile}

Pondok Karya Pembangunan High School (PKP) was founded in 1988 in this location now as an education complex of kindergartens, MI, MTs, high schools, vocational schools, and STIKes. With the foundation of an Islamic based on - religion school, PKP has built the appeal of the Muslim middle class to send their sons / daughters to PKP JIS High School. Up to 2019, PKP High School has graduated 4950 alumni.

Geographically, PKP SMA is close to the buffer zone which is now growing rapidly, namely Depok, Cileungsi, and Bekasi. Simultaneously with the rise of the buffer zone, PKP sociologically participated in changing its class from the target of secondary schools to those of high school.

Social interactions between students who have a lot in common make it easier for schools to identify and socialize. According to Rahmat (2018) the individual defines himself according to the person who influences it. Rahmat's opinion is to reinforce the theory of the interaction of nationalism which is simultaneously positive, because the figure of the founders is also a symbol in giving examples of differences and diversity.

In the 2019/2020 school year PKP Senior High School set the vision of the school, "creating educational institution that is able to produce students who are pious in behavior, excel in achievement and character as a leader.

\subsection{The Concept of Internalization}

The concept of internalization which is developed in Berger's theory is associated with social construction theory. According to social construction theory, reality is socially constructed [13]. The internalization view in Berger's concept is a dialectical stage which consists of: internalization, objectification and externalization. Internalization is the reabsorption of social reality and transforms it from the objective world structure into the structure of subjective awareness. Objectivity means that social activities can form external facts and appear different from the product itself. Whereas, externalization views society as a human product [13].

John (1991) understands social construction in the perspective of a communication tradition that categorizes it as a sociocultural methodology. This theory focuses on the shared meanings and interpretations constructed in community networks and their implications for the construction of organizational life (rules, norms, values, actions accepted by organizations)

Etymologically, internalization shows a process. In KBBI, Indonesian dictionary [23], internalization is defined as comprehending, understanding, and mastering in depth that take place through coaching, guidance and so on.

Mulyana explains that internalization is classified as a process because there is an element of change and time. Internalization is also known as a merging of the union of attitudes, standards of behavior, opinions and so on in one personality [24]. Reber in Mulyana defines internalization as the merging of values in a person. This means that understanding the value obtained must be practicable and have implications on attitude. Ihsan [25] interpreted internalization as an effort made to embed values into students so that they belonged to them.

Kalidjernih [26] claims internalization as a process in which individuals learn to be accepted and at the same time bind themselves into the values and social norms of society 
behavior. Johnson [27] says that internalization is a process by which the orientation of cultural values and expectations are truly combined with the personality system.

Sociologically, experts state that internalization involves an idea, concept and action that moves from outside into some part of mind which controls personality. In psychology, internalization is the process of accepting a set of norms from other people or groups that affect an individual.

According to Hakam [28], the process of internalizing values usually begins with delivering information by introducing someone to the internalized values. Formulation of submitted values can be in the form of standards, rules, laws, formulas, normative propositions. In addition, Hakam [28] states that the internalization process can be carried out through the following stages: first, the value transformation stage, which is the process carried out by the trainer in informing good and bad values. At this stage there is a process of verbal communication; second, the stage of value transformation, which is the process of internationalizing values through two-way communication, resulting in an interaction process; third, the stage of trans-internalization, which is the process of internalizing values through the process of verbal and personality communication by modeling, conditioning, and adapting process.

\subsection{Internalization Model in PKP JIS High School}

The process of values internalization on religious nationalism in PKP JIS SMA can be described as followed:

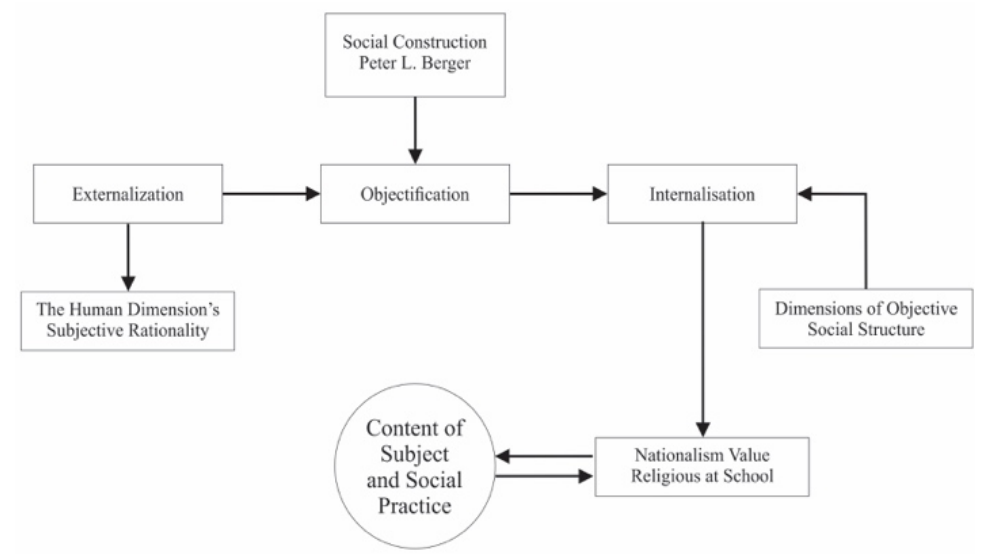

The process of externalization and objectification in PKP JIS Senior High School was carried out through the formation of a school vision that could be translated into mission, goals, culture, programs and strategies for achievement. The process was carried out through exchanging opinions, allowing argument to reach an agreement that has the legal force in the organization. Through various programs or action plans, schools carry out the transmission process to all lines of the organization. As revealed by Berger [29], internalization occurs through socialization mechanisms.

There are two models of socialization conducted by referring to Berger's concept [29]. First, primary socialization is carried out by giving importance and meaning to a policy or program. In this context, the school explains the meaning and significance of diversity as an important part in building nationalism. Secondary socialization mobilizes students to follow 
the school's strategy in introducing the value of religious nationalism. Students are directed to participate in various activities and learn accordingly.

In the process of conducting this action, there are some possible situation in which triggers the transmission or transfer of attitudes and culture. It also unites student values from understanding the subjective dimension (what he feels) to the objective dimension (why it must be carried out).

\subsection{Religious Nationalism}

Nationalism comes from the word nation. In terms of meaning, nationalism is the understanding or teaching process to love the Nation and the State itself. Nationalism also means to provide awareness of citizenship in a nation that lead the people to potentially or actually joint together to achieve, maintain, compare the identity, integrity of the prosperity and strength of the nation. Hara [30] gives an inside to understand nationalism as the equality of membership and citizenship of all ethnic and cultural groups in a nation. Mulyana [17] defines nationalism as the state awareness or national enthusiasm. Nationalism demands the realization of basic values which are oriented towards the common interest and avoids all the legalization of personal interests which undermines general life cycle.

Kartodirdjo [31] views nationalism as a historical momentum that cannot occur without the role of entrepreneurship, creativity, socialism, idealism and social responsibility. In addition, Kartodirdjo [9] states that the main prerequisite of nationalism is that nationalists must guarantee unity among citizens, liberty of individuals and groups, equality for each individual, the realization of personality and performance for excellent future.

An understanding of religious nationalism rpovides an insight in which a type of nationalism shows a situation where the State obtains political legitimacy from religious equality [32]. Sutisna [33] religious nationalism can be interpreted as a religious nationalism in which a State is able to create a nation from diverse tribes. Whereas, Madjid [34] explains that Indonesian nationalism which is based on Pancasila is religious nationalism. In religious nationalism, religion is the basis, which is to place God supremacy in the first principle of Pancasila. Ethnic and religious identity with the addition of power of religiosity, individual attitudes and fundamentalism can enhance cooperation.

\subsection{Views on Diversity}

a) Presidential Election Process

Related to the values of Religious Nationalism, researchers observed a process during the 2019 Presidential election. Students' choices were polarized on two major parties in presidential candidates as seen in a number of poses that showed the symbol of choice; with finger 1 for number 1 and finger 2 for number 2 (symbol specifically existed for candidate number 2 Prabowo - Sandi). Although their polarization seemed to be apparent, there had never been any friction, or excessive criticism and sarcasm.

b) Attitudes towards Ethnicity Differences

$100 \%$ of PKP high school students were Muslim and 100\% of teachers and employees were Muslim. However, people from different faiths were being very well accepted there. In PKP JIS High School, there were two trainers with different religions for Choir and Band trainers and basketball extracurricular trainers. Christian padus coaches had been training for 6 years and were comfortable to continue their training. He also highly appreciated the distinctiveness of the Islamic-based school 
which implement the obligations of worship. Half an hour before Maghrib, the trainer always stopped the activities even though there was still time. This implemented attitude can be seen from the absence of rejection or resistance from the extracurricular participants to the trainers.

c) Nationalism/Unity in Diversity

Islamic High School PKP Islamic based schools learn from various schools with various religious bases, as well as its alumni's choices to continue to their study to universities with various religious background. SMA PKP JIS conducted a comparative study at the Kalimalang Penabur VII and Penabur I (Parent) High Schools in Kyai Tapa. PKP High School also continued conducting comparative studies to the National High School Jubile in the Sunter area, North Jakarta.

\subsection{PKP High School Activities that Support the Creation of Religious Nationalism Values}

a) Flag Ceremony

The flag ceremony on every Monday was a routine activity as a form of training to instill a sense of patriotism and appreciation for the heroes. In the ceremonies, the foundation of Pancasila State and the opening of the 1945 Constitution were read aloud. The participants were also led to sing the National anthem and there was a silent moment to commemorate the merit of the national heroes.

b) National Holiday Ceremony

Activities to commemorate national holidays became the school's obligation in order to remember important events that had occurred in the past. This activity was an encouragement of millennial generation about the historical values and heroism of national figures. In the form of flag ceremony activities that were always held, there was heroes' day, teacher's day, Youth oath day, national education day, national awakening day. These activities were also often completed with the supporting events.

c) Religious Holidays

SMA PKP JIS always celebrated religious holidays. Apart from the school's vision that must be implemented, it was also part of the school program in increasing faith and devotion to Allah Subhanahu wa Ta'ala. The islam clerics presented at PKP JIS Senior High School were gentle, meaning-oriented, not the provocative and hardspeaking ones. Some religious teachers who had appeared at PKP JIS high school events were; (1) Ahmad Al Habsy, (2) Ustad Jaka Tingkir (3) Ust. Fun (Tamsin Amani), (4) Ust. Pantun, etc. Institutionally, inviting several informants such as, Ahmad Al Habsy, Ustad Jaka Tingkir, etc are more motivated by the similarity in moderate thinking. Besides that, the circumstance in the journey of the religious teachers were more likely to offer an adaptable Islam to the religion issues that developed without taking asides in association.

d) State Defending Activities

State defense activities at the PKP JIS High School were carried out by instilling national values through training to selected students. The speakers from outside the school came from the active soldiers who trainned discipline through marching rules.

e) Learning

There were two lessons which was directly related to the theme of Religious Nationalism. The first lesson was history. History was compulsory lessons and 
specialized in examining many things about the values and merits of national heroes, historical events and national patriotism. In History, there was material about war against the colonial. It was discussed in the topics related to negotiations for Indonesian independence. The second lesson is PPKn (Pancasila and Civic Education).

f) Anival Event

Carnival event was a monumental activity for PKP JIS High School. In this event, PKP High School held various activities in which various schools took parts in it despite their background. Some of these activities united various ethnic, religious and school identities. This event had several activities including sports and art competitions, literacy and performance, and fashion by adapting Jember Fashion Carnival (JFC). In JFC research, they designed clothes with the basic values of the selected area. The theme of decoration was also related to the region that we chose. This year's carnival event, the theme was all about the Javanese kingdom.

g) Grand Election

The general election of Students Body President was a miniature of the actual democratic process. The activity of the President election was conducted like the actual presidential election. All standards proposed in the regional head election were carried out in this event. Some activities which were carried out such as campaigns, ballots, ballot boxes, voting booths, ink and direct calculation among other activities. Before the election, the candidates were also allowed to make posters to attract voters.

h) LDKS

LDKS was an activity held by PKP JIS High School to result future leaders. In the short term, LDKS will be prepared as candidates for student council, student scouts, Rohis, etc. Rohis is the organization of Spiritual Islamic that shared about Islamic topics. This activity was followed by the freshmen.

\section{Conclusion}

Religious nationalism is an understanding Millennial generation comprehend in the form of acts to respect differences, accept diversity and respect others as God's creatures.

Millennials also show a positive tradition in introducing the practice of religious nationalism in structured and patterned activities in schools. Subjective involvement is materialized by participating in the flag ceremony, defending the State, LDKS, learning Pancasila and Civic Education (PPKn), History and others.

\section{References}

[1] W. Scheidel, "A model of demographic and economic change in Roman Egypt after the Antonine plague," J. Rom. Archaeol., vol. 15, pp. 97-114, 2002.

[2] D. Mulyana, Metodologi penelitian kualitatif: paradigma baru ilmu komunikasi dan ilmu sosial lainnya. PT Remaja Rosdakarya, 2010.

[3] B. Adler Ronald and G. Rodman, "Understanding Human Communication. New York." Oxford University: Press, 2006.

[4] M. Iriantara, Yosal; Syukri, Komunikasi Kepemimpinan Pendidikan. Bandung: Simbiosa Rekatama Media, 2017. 
[5] J. Fiske, "Culture and communication studies," Yogyakarta: Routledge, 2004.

[6] Y. Latif, Revolusi Pancasila. Mizan, 2015.

[7] Y. Latif, Wawasan pancasila: Bintang penuntun untuk pembudayaan. Penerbit Mizan, 2018.

[8] A. Appadurai, The social life of things: Commodities in cultural perspective. Cambridge University Press, 1988.

[9] S. Kartodirdjo, Multidimensi pembangunan bangsa: Etos Nasionalisme dan Negara kesatuan. Penerbit Kanisius, 1999.

[10] N. Martono, "Sosiologi Perubahan Sosial," Jakarta Raja Graf. Persada, 2011.

[11] Karman, "Kontruksi Realitas Sosial sebagai Gerakan Pemikiran (Sebuah Telaah Teoretis Terhadap Konstruksi Realitas Peter L. Berger)," J. Penelit. dan Pengemb. Komun. dan Inform., vol. 5, no. 3, pp. 11-23, 2015.

[12] S. Hidayat, Teori Proses dan Konteks Sosial Budaya Pendidikan. Jakarta: Pustaka Mandiri, 2019.

[13] P. L. Berger, F. M. Parera, and T. Luckman, Tafsir sosial atas kenyataan: Risalah tentang sosiologi pengetahuan. LP3ES, 1990.

[14] I. B. P. Manuaba, "Cemaran Pestisida Fosfat-Organik di Air Danau Buyan Buleleng Bali," J. Kim. (Journal Chem., 2008.

[15] A. Liliweri, "Komunikasi antar pribadi," Bandung: Citra Aditya Bakti, 1997.

[16] M. D. Mahmud, Psikologi pendidikan: suatu pendekatan terapan. BPFE, 1990.

[17] D. Mulyana and J. Rakhmat, Komunikasi antarbudaya. Remaja Rosdakarya, 1990.

[18] L. J. Moleong, "Metode Penelitian Kualitatif, cetakan ke-36, Bandung: PT," Remaja Rosdakarya Offset, 2017.

[19] S. Kholifah and I. W. Suyadya, "Metodologi Penelitian Kualitatif: Berbagi Pengalaman dari Lapangan," Depok: RajaGrafindo, 2018.

[20] P. Bourdieu, "Participant objectivation," J. R. Anthropol. Inst., vol. 9, no. 2, pp. 281-294, 2003.

[21] M. Seto, "Metode Penelitian Penelitian Kualitatif dan Mixed Method," Depok PT Rajagrafindo Persada, 2019.

[22] R. K. Yin, "Studi Kasus (Desain dan Metode) Penerjemah M,” Djauzi Mudzakir, Jakarta PT. Raja Graf. Persada, 1996.

[23] KBBI, Kamus Besar Bahasa Indonesia. Jakarta: Balai Pustaka, 1989.

[24] J. P. Chaplin, "Kamus Psikologi (Diterjemahkan oleh Kartono)," Jakarta: Rajagrafindo Persada, 2005.

[25] H. F. Ihsan, Dasar-Dasar Kependidikan. Penerbit Rineka Cipta, 1997.

[26] F. K. Kalidjernih, Kamus studi kewarganegaraan: perspektif sosiologikal dan politikal. Widya Aksara Press, 2010.

[27] G. L. Johnson, "Research Methodology for Economists Philosophy and Practice," 1986.

[28] K. A. Hakam, "Pengembangan Model Pembudayaan Nilai-Moral dalam Pendidikan Dasar di Indonesia: Studi Kasus di Sekolah Dasar Negeri Bandungrejosari 1 Kota Malang, Jawa Timur," Sosiohumanika, vol. 4, no. 2, 2011.

[29] P. L. Berger and T. Luckmann, "Langit Suci: Agama Sebagai Realitas Sosial, terj," Hartono. Jakarta: LP3ES, 1991.

[30] N. Hara, "Student distress in a web-based distance education course," Information, Commun. Soc., vol. 3, no. 4, pp. 557-579, 2000.

[31] S. Kartodirdjo, Sejak Indische sampai Indonesia. Penerbit Buku Kompas, 2005.

[32] N. Burhanuddin, "Konstruksi Nasionalisme Religius: Relasi Cinta dan Harga Diri dalam Karya Sastra Hamka," Epistemé J. Pengemb. Ilmu Keislam., vol. 10, no. 2, pp. 353-384, 2015.

[33] A. Sutisna, "Peningkatan Literasi Politik Pemilih Pemula Melalui Pendekatan Pembelajaran Kontekstual," in Prosiding Seminar Nasional Pendidikan FKIP, 2017, vol. 1, no. 2.

[34] Majid, Metodologi Penelitian Pengembangan Untuk Peningkatan Kualitas Pembelajaran (Research Metodology to Improvement of Introduction). Bandung: Gransindo, 2014. 